\title{
The Influence of Price and Non-Price Factors on Acreage Response of Maize in Eswatini
}

\author{
D. V. Dlamini* \\ Department of Agricultural Economics and Management, Faculty of Agriculture, University of Eswatini, Luyengo, Eswatini \\ S. G. Dlamini \\ Department of Agricultural Economics and Management, Faculty of Agriculture, University of Eswatini, Luyengo, Eswatini \\ D. Akelrele \\ Department of Agricultural Economics and Farm Management, Federal University of Agriculture, Abeokuta, Nigeria \\ Q. Jele \\ Department of Agricultural Economics and Management, Faculty of Agriculture, University of Eswatini, Luyengo, Eswatini
}

\begin{abstract}
The study analyzes the acreage response of maize with respect to price and non-price factors in Swaziland during the period 1968-2017. Rainfall and agricultural policy are the non-price factors considered in this study. The Cointergration and Vector Error Correction Modeling approaches were used to estimate the short run and long run elasticities of price and non-price factors acreage response of maize in Eswatini. The results confirm that non-price factors seem to have more effect on acreage response in the long run. The introduction of the Maputo declaration policy in 2003 had not yeld the positive impact on maize annual acreage changes. The study also shows that climatological factors such as rainfall has a positive influence on maize production and resource allocation both in short and long run. Development of climate change mitigation and adaptation strategies would assist the maize production sector in the country. The strategies cannot affect natural conditions like rainfall, but it can compensate for the negative impact of climate change by increasing investment in irrigation, promoting efficient use of water and encouraging adoption of drought resistant varieties of seeds.
\end{abstract}

Keywords: Maize acreage response; Price factors; Non-Price factors; Vector error correction model.

(9) (i) CC BY: Creative Commons Attribution License 4.0

\section{Introduction}

Maize production is one of the most potential cereal crop grown globally, and is the third after wheat and rice in total food grain production [1]. Due to its high adaptability and productivity, the cultivation of maize spread rapidly around the globe and is currently being produced in most countries of the world. In Eswatini maize farming is divided into two which is commercial farming on Title Deed Land (TDL) and subsistence farming on Eswatini Nation Land (SNL). In total agricultural output, maize production on SNL accounts for only 10\%. The country has never reached self-sufficient levels in maize production, while almost every household in SNL produce maize. For the past 40 years, Eswatini has not been able to meet the population's maize requirements [2]. Currently, the domestic shortfalls in maize are covered by imports from South Africa through the National Maize Corporation.

The acreage exploited for growing this crop fluctuates up and down from one year to the next. In 2002/03, a total of 67682 acres were exploited, producing around 69273 tons of maize crop, but this figure soon dropped down in 2003/04 to 54470 acres while the production size jumped to 68087 tons [3]. Out of all the ecological zones of Eswatini, the Highveld comes first as per the acreage used for growing maize crop [3]. A considerable number of studies have focused on agricultural supply and acreage response to price and non-price factors with a wide range of crops over the years [4-10]. However, the nature and extent at which farmers respond to changes in price and nonprice factors still remains a debatable issue.

Liu [11], claimed that, there are many arguments to support the notion that farmers in developing countries are not responsive to economic incentives such as price. The various crop-level studies available for the developing countries have for the most part arrived at the same outcome that the supply response is less elastic than in developed countries. The reasons these studies cite for poor response range from limitations on irrigation and infrastructure to the lack of complementary agricultural policies and subsidies. Furthermore, there are varying results on the degree of response. The reasons for the variation in the results focus on conceptual problems in identifying correct prices and exogenous variables and point to the formulation of empirical models; for instances, the specification of supply function, use of distributed lag, failure to recognize model identification problems and improper choice of noneconomic factors [12]. Generally farmers do respond to incentives, but the response might be restricted and subject to various constraints.

There is no empirical study conducted on acreage response of maize growers in Eswatini. Thus there is intense need to study acreage response of maize growers to price and non-price factors. This will give policy makers 
understanding in allocation of land for maize production. Moreover, reliable estimates of acreage response of maize growers are of greater importance for predicting accurately the farmers' responsiveness towards the price and nonprice factors and for formulating programmes consistent with national requirements of food and fodder [13]. More importantly, expanding cultivated area is a viable option for increasing production [14]. Understanding how producers make decisions to allocate acreage among crops and how decisions about land use is affected by changes in price and their volatility is fundamental for predicting the supply of stable crops and, hence, assessing the global food supply situation [15]. The production decisions of farmers are dependent on various policies of the government. Price policy, amongst the others, is the most important one. That is, farmers would allocate their limited land resources to that crop enterprise toward which the relative price movements tend to be favorable. This is however, quite logical and rational as the allocation of land to a better-priced crop would fetch more revenue to farmers. Responsiveness of farmers to economic incentives such as price could influence contribution of agriculture to economy [16].

The gap between planting and harvest guarantees that agricultural producers do not know in advance what price they will receive for their product and the random nature of production ensures that producers do not know in advance what their yield will be. The knowledge on the extent to which agricultural sector responds is not only important in understanding the dynamics of production, but also for planning public programmes, mindful of the producer behavior and response to prices [17].

Hence the objective of the study was to estimate the short and long run elasticities of price and non-price factors. The no-price factors include average rainfall and the policy variable being the Maputo declaration to increase agricultural expenditure to 10 percent of GDP acreage response of maize in Eswatini.

\section{Methods and Materials}

The study is focused on Eswatini located at the southern part of Africa. The country is divided into four regions namely Manzini region, Shiselweni region, Hhohho region and the Lubumbo region. Maize is produced throughout Eswatini with the Highveld areas being the largest producer. The Highveld area have comparatively higher average yield about 6MT per hectare [3]. The focus of the study area has been chosen because almost all of Eswatini's area and almost everyone grows maize. Maize is also the staple food or the main grain for a large section of the population of Eswatini.

The study adopted time series design. The defining feature of time series research design is that each participant or sample is observed multiple times, and its performance is compared to its own prior performance. In other words, each participant or population serves as its own control.The historical time-series data for the period of 50 years (1968-2017) pertaining to maize area planted, maize price, maize production, rainfall, sorghum price and rice price was collected from various published sources. Data pertaining maize area planted, maize production, maize prices, sorghum prices and rice prices were obtained from Food and Agriculture Organization [18]. Database; Rainfall data was obtained from Eswatini Meteorological Services.

Prior to the estimating the short and long-run elasticities of price and non-price factors on acreage response of maize in Eswatini there is a need to examine each of the variables for the presence of unit root and for this study we have adopted the Augmented Dickey-Fuller (ADF) test.. The ADF unit root test normally follows the first order auto-regressive processes and includes the first order difference in lags in the test in such a way that the error-term is distributed as a white noise process.

The equation for the ADF test is:

$$
\Delta V_{t}=\beta V_{t}-1+\sum j a j \Delta Y_{t-1}+\theta
$$

Where, $\mathrm{Y}$ is the processes to be tested, $\beta$ is the coefficient to be tested, and $\mathrm{j}$ is the lag length chosen for the ADF such that $\mathrm{u}_{\mathrm{t}}$ is a white noise process. Here, the significance of $\beta$ is tested against the null hypothesis to find that the process is not weak (non-stationary). Thus, if the null hypothesis of not weak stationary cannot be rejected, the variables are differenced until they become stationary (until the existence of unit root is rejected).

In order to analyze both the long-run and short-run behavior of the variables there is a need for the series to be integrated and co-integrated [19]. In this paper the co-integration analysis was performed using Johansen approach. The Johansen technique provides two likelihood ratio tests, namely the Trace and the Maximum Eigen value statistic test, which are mainly used to determine the number of co-integration equations given by the co-integration rank $\mathrm{r}$. A co-integration equation is the long-run equation of co-integration series. The Trace statistic tests the null hypothesis of $\mathrm{r}$ co-integration vectors against the alternative of $\mathrm{k}$ co-integration relations, where $\mathrm{k}$ is the number of endogenous variables for $\mathrm{r}=1,1, \mathrm{k}-1$. The maximum Eigen Value statistic tests the null hypothesis of $\mathrm{r}$ co-integration vectors against the alternative of $\mathrm{r}+1$ co-integration vectors [7].

If the series $\mathrm{Y}_{\mathrm{t}}$ and $\mathrm{X}_{\mathrm{jt}}$ are integrated and co-integrated, then the Error Correction Model is represented in the following form;

$$
\Delta Y_{t}=c+\beta i \Delta Y t-1+\sum j \Delta X_{t-1}+\delta E C T t-1++\theta t
$$

Where

$\mathrm{ECT}_{\mathrm{t}-1}$ - is the error correction term derived from the long-run co-integration relation

$\Delta-$ is the difference Operator

$\mathrm{Yt}$ - is the maize acreage

$\mathrm{X}_{\mathrm{jt}}$ - represents the independent variables (maize price, temperature, 
The policy variable is represented by dummy variable for years before and after the Maputo declaration (period 1: 1991-2003; period 2: 2003-2014). Period 1 and 2 takes the values of 0 and 1 respectively.

\section{Results and Discussion}

\subsection{ADF Test for Stationary}

Time series procedure for testing the variables for unit roots was done. The data series on annual yield, area planted, price of maize, price of sorghum, and price of rice, rainfall and area was tested for unit root for a period of 1968-2017 using the Augmented Dickey Fuller test. The unit root test results are presented in Table 1 and 2.

Table-1. Results of unit root test at levels

\begin{tabular}{l|l|l|l|l|l}
\hline Series & $\begin{array}{l}\text { ADF test } \\
\text { statistic }\end{array}$ & Critical value & Lag-length & Probability & Conclusion \\
\hline $\begin{array}{l}\text { Lmaize Area } \\
\text { Planted }\end{array}$ & -4.09 & -2.933 & 0 & 0.0010 & Stationary \\
\hline Lsorghum Price & -0.611 & -2.933 & 0 & 0.8684 & Non-Stationary \\
\hline Lrice Price & -0.414 & -2.933 & 0 & 0.9077 & Non-Stationary \\
\hline
\end{tabular}

Table-2. Results of unit root test at first differences

\begin{tabular}{l|l|l|l|l|l}
\hline Series & $\begin{array}{l}\text { ADF test } \\
\text { statistic }\end{array}$ & $\begin{array}{l}\text { Critical } \\
\text { value }\end{array}$ & Lag-length & Probability & Conclusion \\
\hline LMaize price & -7.163 & -2.936 & 1 & 0.0000 & Stationary \\
\hline LSorghum price & -7.503 & -2.936 & 1 & 0.0000 & Stationary \\
\hline LRice price & -16.653 & -2.936 & 1 & 0.0000 & Stationary \\
\hline
\end{tabular}

All variables are in log form. The ADF method test the hypothesis that H0: that is, no unit root (stationary) against H1: that is has unit root (non-stationary). The critical values for the rejection of the null hypothesis of unit root are all significant at $5 \%$. The results of the unit root tests showed that rainfall is stationary at levels, while Lmaize price, Lsorghum price, Lrice price, Lmaize area planted, and Lmaizearea planted is not stationary at levels as shown in Table 1 above. All the non-stationary series were stationary after the first differencing. From Table 1 the null hypothesis of unit root could not be rejected at levels since not all series except rainfall of the ADF test statistics were greater than the relevant critical values. Therefore the null of the presence of unit root is accepted. However, the hypothesis of unit root in all series was rejected at 5\% level of significance for all series after first difference since the ADF test statistics are greater than the respective critical values as shown in Table 2.

\subsection{Short-Run and Long-Run Maize Supply Response to Price and Non-Price Factor}

Table 3 presents the co-integration results and confirms the presence of one co-integrating equation at $5 \%$ level of significance.

Table-3. Cointegration Results

\begin{tabular}{l|l|l|l}
\hline Maximum rank & Eigenvalue & Trace statistics & $\mathbf{5 \%}$ critical value \\
\hline 0 &. & 111.4201 & 94.15 \\
\hline 1 & 0.61969 & $65.0155^{*}$ & 68.52 \\
\hline 2 & 0.41997 & 38.8708 & 47.21 \\
\hline 3 & 0.31827 & 20.4807 & 29.68 \\
\hline 4 & 0.26809 & 5.4997 & 15.41 \\
\hline 5 & 0.10086 & 0.3967 & 3.76 \\
\hline 6 & 0.00823 & & \\
\hline
\end{tabular}

The trace statistics at maximum rank 1 which is 65.0155 was less than the critical value which is 68.52 which means that there is one co-integrating equation or variables have got long run response. The cointegration tests were to test whether there was a statistical significant linear response between the variables. Trace statistics are consistent in suggesting that there are cointegrating vectors among the variables. This suggest that the maize price, sorghum price, rice price, rainfall and policy were cointegrated and had both short run and long run response with the maize area planted. The results showed the existence of one cointegrating vectors and the rejection of the null hypothesis of $\mathrm{r}=0$ which states that there is no cointegration among the variables, based on both the trace test and maximum Eigen value test. Thus, there is a long run cointegrating response among the variables. 


\subsection{Results of the VEC Model for Long-run Maize Acreage Response to Price and Non- Price Factors}

Table-4. Long-run vector error correction estimates

\begin{tabular}{l|l|l|l|l}
\hline Variable & Coefficient & Standard error & $\mathbf{Z}$ & $\mathbf{p}>|\mathbf{z}|$ \\
\hline Constant & --2189 &. &. &. \\
\hline & 1 &. &. &. \\
\hline Log maize price & 0.3544 & 0.5999 & 0.59 & 0.555 \\
\hline Log sorghum price & 0.9623 & 0.3453 & 2.79 & $0.005^{* *}$ \\
\hline Log rice price & -1.1560 & 0.3366 & -3.43 & $0.001^{* *}$ \\
\hline Log rainfall & -0.7961 & 0.3328 & -2.39 & $0.017 * *$ \\
\hline Policy & -0.2828 & 0.1741 & -1.62 & 0.104 \\
\hline **significant at 5\% level \\
* significant at 10\% level
\end{tabular}

The results in Table 4 show that maize area planted in the long run is dependent on maize price, sorghum price, rice price, rainfall and policy. The maize price was not significant in the long run however, it has a positive coefficient. In contrast, the sorghum price was significant in the long run, with a positive coefficient of 0.962 . This means that a percentage increase in sorghum price will cause a 0.962 percent increase in the maize area planted. Rice price was also significant with a negative coefficient of 1.156 and this means that a percentage increase in the rice price will cause a 1.156 percent decrease in the maize area planted in the long run. This is due to the fact that when the price of substitute which is rice increases, the farmers will then allot their acreage to the substitute crop instead of the main crop which is maize. Rainfall variable was significant in the long run with a negative coefficient of 0.796 , which means that a percentage increase in rainfall will cause a 0.796 percent decrease in the area planted in the long run. This indicates that farmers are responding negatively towards rainfall in the long run. The policy variable was insignificant in the long run with a negative coefficient of 0.283 .

\subsection{Short-Run Maize Acreage Response to Price and Non-Price Factors}

Table-5. Short-run Vector Error Correction estimates

\begin{tabular}{l|l|l|l|l}
\hline Variable & Coefficient & Standard error & $\mathbf{Z}$ & $\mathbf{p}>|\mathbf{z}|$ \\
\hline Constant & -0.0246273 & 0.0301247 & -0.82 & 0.414 \\
ECM & 0.0010367 & 0.0007591 & 1.37 & 0.172 \\
\hline Log maize area planted & -0.1111522 & 0.1512609 & -0.73 & 0.462 \\
\hline Log maize price & 0.1561295 & 0.1922364 & 0.81 & 0.417 \\
\hline Log sorghum price & 0.1707896 & 0.1238261 & 1.38 & 0.168 \\
\hline Log rice price & -0.1807844 & 0.1387058 & -1.30 & 0.192 \\
\hline Log rainfall & 0.1240107 & 0.1070758 & 1.16 & 0.247 \\
\hline Policy & -0.2729171 & 0.1857837 & -1.47 & 0.142 \\
**significant at 5\% level & \multicolumn{5}{|l}{}
\end{tabular}

In the Table 5, the elasticity of maize area planted was $11.1 \%$. Most parameter estimates were within reasonable ranges suggesting a relatively strong short-run supply response to prices, meaning an increase in maize area planted in the short-run will lead to a decrease in the price of maize. The negative sign of the maize area planted suggest that given the existence of a market glut, maize could be replaced with its substitutes such as sorghum and rice. In other words an increase in maize supply resulting in a decline in its price will make farmers to shift maize area planted to its close substitutes, thereby reducing its area planted. The maize price elasticity in the short-run was 0.156 and that of sorghum price and rice price were 0.171 and -0.181 respectively suggesting that a percentage increase in the prices of maize and its substitutes led to a less that proportionate percentage increase in the maize area planted in the short-run. This means that maize farmers in Eswatini did not make adequate short-run maize area planted expansion adjustment in response to changes in maize price. This is due to that inputs such as land are fixed in the short-run, farmers cannot be able to increase the maize area planted in the short run.

\section{Conclusion and Recommendations}

This study estimated the long run and short run elasticities using the Vector Error Correction (VEC) model. National historical time series data for the period 1968-2017 was used. Production variables for the area planted model with the ability to evaluate the stated hypothesis were identified and selected according to the availability of data. The acreage response functions were applied to detect the impact of price and non-price factors on changes in maize output in Eswatini. All data series were converted to logarithmic form and were also tested for stationarity before being used in the supply functions. The study found that maize area planted does not respond well to price factors in the short run. Therefore it is recommended that the government should set up distinctive market price mechanisms which should be acceptable to farmers in order to attain self-sufficiency in production such as setting a minimum procurement price and providing inputs subsidies. Subsidies for producing grain and purchasing input 
encourage farmers to improve maize production. If prices are properly stabilized, farmers will adopt scientific and improved methods of cultivation and due to this agricultural production especially maize production will be enhanced to meet the national food requirements of the country. The study also found out that variations in maize prices do not significantly explain area adjustment in the long run, due to fixed inputs such as land and capital. Therefore it is recommended that government should provide farmers with more land and capital so that farmers can be able to respond to the maize price changes in the long run.

\section{References}

[1] Anupama, J. S., 2005. "Technical efficiency of maize production in Madhya Pradesh, Estimation and implications." Agric. Econ. Res., vol. 18, pp. 305-315.

[2] National Maize Corporation, 2010. "Swaziland, National Maize Corporation (Pty) LTD."

[3] CSO, 2005. CSO mission and yield estimates. Mbabane, Eswatini.

[4] Bailey, K. W. and Womack, A. W., 1985. "Wheat acreage response, A regional econometric investigation." Southern Journal of Agricultural Economics, pp. 171-181. Available: https://ageconsearch.umn.edu/record/29977/

[5] Mahmood, M. A., Sheikh, A. D., and Kashif, M., 2007. "Acreage supply response of rice in Punjab, Pakistan." Journal of Agricultural Research, vol. 45, pp. 231-236.

[6] Leaver, R., 2004. "Measuring the supply function of tobacco in Zimbabwe." Agrekon, vol. 43, pp. 113 131.

[7] Triphathi, A., 2008. "Estimated agricultural supply response by Co-integration approach." Report submitted under visiting research scholar programme available.

[8] Tey, Y. S., Darham, S., Noh, A. F. M., and Idris, N., 2009. "Acreage response of Rice, A Case study in Malaysia."

[9] Techereni, B. H. and Techereni, T. H., 2013. "Supply response of maize to price and non- price incentives in Malawi." Journal of Economics and Sustainable Development, vol. 4, pp. 141- 152.

[10] Nijlaa, S. R., 2017. "The influence of price and non-price factor an acreage response of maize in Iraq." Imperial Journal of Interdisciplinary Research, vol. 3,

[11] Liu, F. Y., 2010. "Dynamic agricultural supply response under economic transformation" A case study of Heran Province. IFPRI discussion paper (00987).

[12] Gulati, A. and Kelly, A., 1999. Trade Liberalization and Indian Agriculture. United Kingdom: Oxford University Press.

[13] Bakhtawar, R. S., 1997. "Acreage response analysis on Maize growers in Kyber Phakhtunkhwa, Pakistan." International Journal of Food and Agricultural Economics, vol. 2, pp. 33-44.

[14] Molua, E., 2010. "Price and non-price determinants and response of rice in Camerron." ARPN, Journal of Agricultural and Biological Sciences, vol. 5, pp. 20-25.

[15] Haile, M. K., Kalkuhl, M., and Barun, J. V., 2013. "Short-term global crop acreage response to international food prices and implications of volatility." ZEF-Discussion Paperson Develoment Policy No.175, p. 38. Available: https://papers.ssrn.com/sol3/papers.cfm?abstract_id=2226943

[16] Mushtaq, K. and Dawson, P. J., 2002. "Acreage response in Pakistan: A cointergration approach." Agricultural Economics, vol. 27, pp. 111-121.

[17] Mckay, A. M., 1999. "Aggreagete agricultural supply response in Tanzania." Journal of International Trade and Economic Development, vol. 8, pp. 107-123.

[18] FAO/WFP, 2005. "Crop and food supply assessment mission to Swaziland. Special Report, Mbabane."

[19] Engle, R. A., 1987. "Cointegration and error correction representation, Estimation and testing." Econometrica, vol. 55, pp. 251-275. 